J. Dairy Sci. 92:599-606

doi:10.3168/jds.2008-1564

(c) American Dairy Science Association, 2009.

\title{
Production loss due to new subclinical mastitis in Dutch dairy cows estimated with a test-day model
}

\author{
T. Halasa, ${ }^{\star} \dagger^{1}$ M. Nielen, ${ }^{\star}$ A. P. W. De Roos, $\neq$ R. Van Hoorne, $\neq$ G. de Jong,‡ T. J. G. M. Lam, $† \S$ \\ T. van Werven, ${ }^{\star} \S$ and H. Hogeveen*† \\ *Department of Farm Animal Health and Reproduction, Utrecht University, PO Box 80151, 3584 CN Utrecht, the Netherlands \\ †Business Economics Group, Wageningen University, PO Box 8130, 6706 KN Wageningen, the Netherlands \\ ¥NRS, PO Box 454, 6800 AL Arnhem, the Netherlands \\ §Dutch Udder Health Center at the Animal Health Service Ltd., PO Box 9, 7400 AA Deventer, the Netherlands
}

\section{ABSTRACT}

Milk, fat, and protein loss due to a new subclinical mastitis case may be economically important, and the objective of this study was to estimate this loss. The loss was estimated based on test-day (TD) cow records collected over a 1-yr period from 400 randomly selected Dutch dairy herds. After exclusion of records from cows with clinical mastitis, the data set comprised 251,647 TD records from 43,462 lactations of 39,512 cows. The analysis was carried out using a random regression testday modeling approach that predicts the cow production at each TD based on the actual production at all previous TD. The definition of new subclinical mastitis was based on the literature and assumed a new subclinical case if somatic cell count (SCC) was $>100,000$ cells $/ \mathrm{mL}$ after a TD with $\mathrm{SCC}<50,000$ cells $/ \mathrm{mL}$. A second data set was created by applying an adjustment to correct low SCC for the dilution effect when determining if the previous test-day SCC was $<50,000$ cells / $\mathrm{mL}$. Thereafter, the loss was estimated for records with SCC $>100,000$ cells $/ \mathrm{mL}$. The production (milk, fat, or protein) losses were modeled as the difference between the actual and predicted production (milk, fat, or protein) at the TD of new subclinical mastitis, for 4,382 cow records, and 2,545 cow records after dilution correction. Primiparous cows were predicted to lose 0.31 $(0.25-0.37)$ and $0.28(0.20-0.35) \mathrm{kg}$ of milk/d at an SCC of 200,000 cells/mL, for unadjusted and adjusted low SCC, respectively. For the same SCC increase, multiparous cows were predicted to lose $0.58(0.54-0.62)$ and $0.50(0.44-0.56) \mathrm{kg}$ of milk/d, respectively. Moreover, it was found that the greater the SCC increase above 100,000 cells $/ \mathrm{mL}$, the greater the production losses. The estimated production losses were more precise than previously reported estimates.

Received July 18, 2008.

Accepted September 25, 2008.

${ }^{1}$ Corresponding author: t.h.halasa@uu.nl
Key words: production loss, new case, subclinical mastitis, test-day model

\section{INTRODUCTION}

Subclinical mastitis affects milk quality and quantity causing great economic loss for producers (Swinkels et al., 2005; Halasa et al., 2007). Several studies have estimated milk production loss due to subclinical mastitis (e.g., Hortet and Seegers, 1998; Koldeweij et al., 1999), but a wide range of estimates have been reported (Seegers et al., 2003). This variation is caused not only by different populations or mastitis indicators (Hortet et al., 1999) but also by the use of different analytical approaches (Hortet and Seegers, 1998). Estimates of changes in milk composites are scarce and not appropriate for economic calculations (Seegers et al., 2003). Recently, a dilution effect due to high production and low SCC was quantified, suggesting an overestimation of SCC-related production loss in earlier research (Green et al., 2006). Economically, it might be important to correct the estimated production loss for the dilution effect to be able to precisely quantify economic effects of subclinical mastitis. Precise estimation of milk production loss and milk composite changes due to a new subclinical mastitis case is important for good economic calculations in light of treatment decisions. Moreover, reliable economic calculations are important to motivate farmers to adopt management practices.

Several approaches have been proposed to estimate milk production loss at the herd level (e.g., De Graaf and Dwinger, 1996). They have focused on comparing the production of infected and uninfected cows or production before and after infection in the same animal (Hortet and Seegers, 1998; Rajala-Schultz et al., 1999). The introduced variation between animals using the first methodology would decrease the precision of the results. Random regression test-day modeling (RRTM) has been developed to analyze test-day (TD) records of dairy cattle for genetic evaluation (Jamrozik and 
Schaeffer, 1997). Besides fixed effects such as parity, lactation stage, and season, the RRTM includes genetic and nongenetic animal effects and herd-specific lactation curves (De Roos et al., 2004). De Roos and De Jong (2006) presented an RRTM to analyze TD milk urea and used that model to extend lactation curves by using only the TD records up to a certain point in time. The predicted TD productions later in lactation were compared with actual TD productions to evaluate whether a cow was producing more or less than initially predicted. Because such predictions are based on cow- and herd-specific lactation curves, they are very accurate, which makes this approach attractive for estimation of the effect of environmental factors, such as diseases, on subsequent lactation production.

The aim of this research was to estimate milk production loss and changes in milk composites following a new subclinical mastitis case based on the RRTM.

\section{MATERIALS AND METHODS}

\section{Data}

For the purpose of improving udder health in the Netherlands, the Dutch Udder Health Center (Deventer, the Netherlands) in cooperation with dairy herd improvement organizations (CR Delta and NRS, Arnhem, the Netherlands) collected cow production and clinical mastitis records. Initially, 600 farms were selected randomly from the Dutch dairy herd improvement association records. To be selected, farm size had to be at least 50 cows, age of the farmer had to be $<57$ yr, and farmers had to complete a questionnaire and agree to data collection. The data collection took place in 400 farms from July 1, 2004, to June 30, 2005, on the basis of a herd TD interval (TDInt) of 3 to $6 \mathrm{wk}$. For the present study, if clinical mastitis occurred, TD records of the remainder of the lactation were excluded. Clinical records were based on farmer diagnosis of inflamed udder, abnormal milk color, and (or) presence of clots in the milk. The data set consisted of 251,647 TD records from 43,462 lactations of 39,512 cows. The NRS provided cow identification number, herd identification number, lactation number, SCC $\times 10^{3}$ cells $/ \mathrm{mL}$, milk $(\mathrm{kg})$, fat $(\mathrm{g})$, and protein (g) production, calving date, and test date. Clinical mastitis dates were provided by the Dutch Udder Health Center.

\section{Definition of a New Subclinical Mastitis Case}

The definition of a new case of subclinical mastitis was as follows: If at $\mathrm{TD}_{i-1} \mathrm{SCC}<50,000$ cells $/ \mathrm{mL}$ and at $\mathrm{TD}_{i} \mathrm{SCC}>100,000$ cells $/ \mathrm{mL}$, a cow was considered to have a new subclinical mastitis case at $\mathrm{TD}_{i}$, where
$\mathrm{TD}_{i}$ is the record of the new subclinical mastitis $\mathrm{TD}$ and $\mathrm{TD}_{i-1}$ is the previous TD. Cases were included only when both $\mathrm{TD}_{i-1}$ and $\mathrm{TD}_{i}$ were within the same lactation. Moreover, only lactations that started with a calving during the trial period were included in the definition of a new subclinical mastitis case. Only records of the first subclinical mastitis case were included in the analysis.

\section{Dilution Effect}

Recently, it has been noted that low SCC has an inverse relationship with high milk production because of a dilution effect (Green et al., 2006). The dilution was apparent for low SCC $(<50,000$ cells $/ \mathrm{mL})$ and highproducing cows, which indicated that the high yield caused underestimation of the true concentration of the SCC. For SCC $>100,000$ cells $/ \mathrm{mL}$, the inflammation caused high SCC and dilution was negligible. For the current analysis, the lambda $(\lambda)$ value $(0.485)$ of Green et al. (2006) was used to correct for dilution effect for animals with crude SCC $<50,000$ cells $/ \mathrm{mL}$ and milk production $>10 \mathrm{~kg} / \mathrm{d}$ as follows:

$$
\begin{gathered}
\text { Adjusted SCC }=\text { crude SCC } \\
+(-\lambda \times \text { actual milk production }) .
\end{gathered}
$$

After adjustment, $\mathrm{SCC}$ at $\mathrm{TD}_{i-1}$ would increase relative to actual milk production above $10 \mathrm{~kg} / \mathrm{d}$. This means that the SCC of some cows that were selected to be free of subclinical mastitis with $\mathrm{SCC}<50,000$ cells/ $\mathrm{mL}$ at $\mathrm{TD}_{i-1}$ actually exceeded this limit after SCC adjustment. Those cows were therefore excluded and the resulting smaller data set was analyzed separately.

\section{Data Set Construction Based on the RRTM}

Predicted milk, fat, and protein production were calculated by the NRS (Arnhem, the Netherlands) based on the RRTM (De Roos et al., 2004; De Roos and De Jong, 2006). The model is based on a combined analysis of TD production (known means and variances), herd-specific regression curves, and standard lactation curves. Predictions of milk, fat, or protein production were provided for $\mathrm{TD}_{i}$ based on the production at all previous TD corrected for random genetic and fixed environmental effects, parity, DIM, and other important effects. The RRTM is presented and explained in more detail in the Appendix.

The predicted production at $\mathrm{TD}_{i}$ represents the production of the cow assuming that the SCC and all other factors remained the same as for at $\mathrm{TD}_{i-1}$. The difference $(\Delta$ Prod $)$ between the actual and predicted 
production (kilograms of milk, grams of fat, or grams of protein) at $\mathrm{TD}_{i}$ would reflect the effect of SCC (cells/ $\mathrm{mL}$ ) increase, as a marker of new subclinical mastitis, on production:

$$
\begin{aligned}
& \Delta \text { Prod }=\text { actual production at } \mathrm{TD}_{i} \\
& - \text { predicted production at } \mathrm{TD}_{i},
\end{aligned}
$$

where $\Delta$ Prod represents the change in production (kilograms of milk, grams of fat, or grams of protein) at the TD of new subclinical mastitis $\left(\mathrm{TD}_{i}\right)$. Only the first subclinical mastitis case per cow was considered in the analysis in order not to bias the results due to the effect of previous subclinical cases. Cows that started the lactation with $\mathrm{SCC}>50,000$ cells $/ \mathrm{mL}$ were excluded to be able to use predicted production based only on healthy TD before the new case.

\section{Statistical Analysis}

Change in production ( $\Delta$ Prod) at $\mathrm{TD}_{i}$ was modeled using Proc Mixed (SAS Institute, 2004). The models were fitted using the REML method and a backward stepwise regression procedure for the change $(\Delta)$ in milk, fat, or protein production, according to the following model equation:

$$
\begin{aligned}
& Y_{h j k l}=\beta_{0}+\beta_{1} \times \operatorname{LnSCC}+\beta_{2} \times \text { Parity }_{h}+\beta_{3} \\
& \times \text { TDInt }_{j}+\beta_{4} \times \operatorname{DIM}_{k}+\operatorname{Herd}_{l}+e_{h j k l},
\end{aligned}
$$

where $Y_{h j k l}$ is the $\Delta$ Prod at the new subclinical mastitis TD $\left(\mathrm{TD}_{i}\right)$ for each cow in herd $l$ in parity $h$ with a TD interval class $j$, and in DIM class $k ; \beta_{0}$ is the overall mean $\Delta$ Prod at $\mathrm{TD}_{i} ; \beta_{1}$ is the regression coefficient of the natural logarithm of the SCC $\times 10^{3}$ cells $/ \mathrm{mL}(\mathbf{L n}$ SCC); LnSCC is the fixed effect of $\operatorname{LnSCC}$ at $\mathrm{TD}_{i}$ on $\Delta \operatorname{Prod} ; \beta_{2}$ is the regression coefficient of the $h$ th class of parity; Parity ${ }_{h}$ is the fixed effect of class $h$ of parity ( 5 classes, parity $=1,2,3,4$, and $\geq 5$ ) on $\Delta$ Prod; $\beta_{3}$ is the regression coefficient of the $j$ th class of TD interval; TDInt is the fixed effect of class $j$ of the time interval between $\mathrm{TD}_{i-1}$ and $\mathrm{TD}_{i}$ (4 classes, 3, 4, 5, and $\geq 6 \mathrm{wk}$ interval); $\beta_{4}$ is the regression coefficient of the $k$ th class of DIM; $\mathrm{DIM}_{k}$ is the fixed effect of class $k$ of DIM (30 classes) at $\mathrm{TD}_{i} ; \operatorname{Herd}_{l}$ is the random effect of herd $l$; and $e_{h j k l}$ is the residual error.

Separate models were run for each production parameter (milk, fat, or protein). No correlation structure was fitted because only one record per cow existed in the model, which is the $\Delta$ Prod corresponding to the new subclinical mastitis $\mathrm{TD}\left(\mathrm{TD}_{i}\right)$. For the same reason, a cow as a random effect was not included. The estimated loss from each model was assumed to exist in the interval around $\mathrm{TD}_{i}$, from halfway between $\mathrm{TD}_{i-1}$ and $\mathrm{TD}_{i}$ to halfway between $\mathrm{TD}_{i}$ and $\mathrm{TD}_{i+1}$, which is the TDInt of a specific herd. The fit of the models was examined using normality of the residuals and homoscedasticity of the fitted values.

The analysis was carried out on 2 subsets of the final data set that included records at $\mathrm{TD}_{i} ; 1$ ) all $\mathrm{TD}$ records at $\mathrm{TD}_{i}$ were included to represent the effect of new subclinical mastitis on production without adjustment of $\mathrm{SCC}$ at $\mathrm{TD}_{i-1}$ for dilution effect; 2) a subset of data set 1 where records with $\mathrm{SCC}$ at $\mathrm{TD}_{i-1}>50,000$ cells $/ \mathrm{mL}$ after adjustment for the dilution effect were removed. The 2 subsets were analyzed separately according to equation [3] to show results when adjustment of SCC to dilution was considered and when adjustment was ignored.

\section{RESULTS}

\section{Descriptive Analysis}

Number of cows, TD records, and distribution of milk production parameters per parity are shown in Table 1; TD records following clinical mastitis were excluded from that lactation. Of the total number of lactations, $13.3 \%$ of the heifers and cows had a first clinical mastitis case in lactation and $77 \%$ occurred during the first $60 \mathrm{~d}$ of the lactation. No information was available about second or more clinical cases per cow. Mean (SD) milk production for primiparous cows was $23.2 \mathrm{~kg} / \mathrm{d}(6 \mathrm{~kg} / \mathrm{d})$ with a geometric mean SCC of 65,000 cells/mL $(2,660$ cells $/ \mathrm{mL})$. For multiparous cows mean, milk production was $28.3 \mathrm{~kg} / \mathrm{d}(9.2 \mathrm{~kg} / \mathrm{d})$ with a geometric mean SCC 105,000 cells/mL (3,230 cells/ $\mathrm{mL}$ ) (Table 1). Primiparous cows comprised $31.6 \%$ of the whole study population. Test-day interval varied on the cow level between 3 wk ( $1.2 \%$ of the records), 4 wk (69.9\%), $5 \mathrm{wk}(15.2 \%), 6 \mathrm{wk}(10.6 \%)$, and $>6 \mathrm{wk}$ $(3.1 \%)$ intervals.

\section{Milk, Fat, and Protein Production Losses}

The new subclinical mastitis cases were distributed throughout the lactation, where $31,37,22$, and $10 \%$ of the cases occurred in the first 100 DIM, between 100 and 200 DIM, between 200 and 300 DIM, and >300 DIM; respectively. There was no significant difference in production loss among different parities of multiparous cows; thus, the results are presented for primiparous (parity $=1$ ) and multiparous (parity $\geq 2$ ) cows. The TDInt classes did not significantly affect the change in milk, fat, or protein production. For instance, when adjustment to dilution was not considered and for the 
Table 1. Number, mean, and standard deviation of test-day (TD) records of milk $(\mathrm{kg} / \mathrm{d})$, fat $(\mathrm{g} / \mathrm{d})$, and protein (g/d) production and the geometric mean and standard deviation of SCC per parity for 1-yr data on 400 Dutch dairy farms

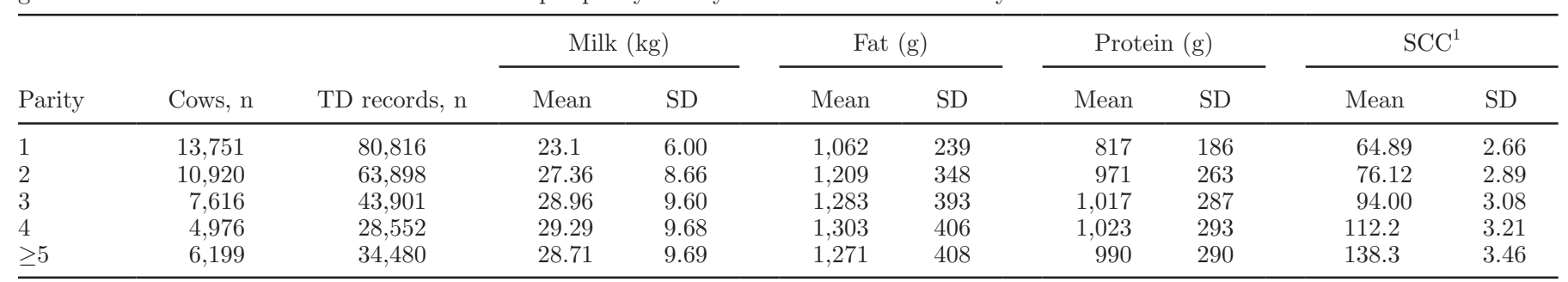

${ }^{1}$ Geometric mean of the crude $\mathrm{SCC} \times 10^{3}$ cells $/ \mathrm{mL}$.

classes $3,4,5$ and $\geq 6 \mathrm{wk}$ intervals, and using the $3 \mathrm{wk}$ interval as the reference class, the coefficient and standard errors were $0.23(0.19), 0.21(0.17), 0.22(0.18)$, respectively. Moreover, changing the reference class did not change the insignificancy of TDInt classes toward the change in milk, fat, or protein production models. Similarly, none of the 30 classes of DIM were found to affect the change in milk, fat, or protein production significantly (lowest $P$-value $=0.65$ ). Therefore, TDInt and DIM were not included in the reduced final models.

The number of new subclinical mastitis cases was 1,372 and 3,010 for primiparous and multiparous cows, respectively. The regression coefficient $\lambda$ was found to be -0.491 . After adjustment to dilution effect, the number of primiparous and multiparous cows that had adjusted $\mathrm{SCC}<50,000$ cells/mL was 989 and 1,556, respectively. The median SCC before adjustment was 40,000 cells/mL, but after adjusting the SCC values according to equation [1] the median value (including cows that exceeded 50,000 cells/mL after adjustment) was 48,000 cells $/ \mathrm{mL}$.

The parameter estimates are presented in Table 2 based on the final models as reduced from equation [3] for the 2 subsets with or without adjusted SCC. The prediction of each model represents the loss in production estimated for $\mathrm{TD}_{i}$; that is, per day. In Table 3 the predicted loss in milk production is presented for different crude SCC values together with the $95 \%$ confidence intervals. For example, a primiparous and a multiparous cow with a SCC of 200,000 cells $/ \mathrm{mL}$ were predicted to lose $0.31(0.25-0.37)$ and $0.58(0.54-0.62)$ $\mathrm{kg}$ of milk per day, respectively, when dilution effect was not considered to select healthy cows at $\mathrm{TD}_{\mathrm{i}-1}$. When the dilution effect was considered to select healthy cows at $\mathrm{TD}_{\mathrm{i}-1}$, a primiparous and a multiparous cow with a SCC 200,000 cells $/ \mathrm{mL}$ were predicted to lose 0.28 $(0.20-0.35)$ and $0.50(0.44-0.56) \mathrm{kg}$ of milk per day, respectively. Table 3 also shows the dose-effect relationship between the increase of SCC and production loss. When the SCC increase exceeds 100,000 cells/mL, the production losses increase.

\section{Fit of the Models}

Figures 1a and $\mathrm{b}$ show the distribution of the standardized Pearson residuals of the models for 2 data sets, for $\Delta$ kilograms of milk. A long tail exists on the right side, which might have caused disturbance of the normality. However, the normality of the residuals is acceptable in both situations. In Figures $2 \mathrm{a}$ and $\mathrm{b}$ the fitted values of the same models are shown. A slight

Table 2. The intercept $\left(\beta_{0}\right)$ and coefficient $\left(\beta_{1}\right)$ of the natural logarithm of SCC $\times 10^{3}$ cells $/ \mathrm{mL}(\mathrm{LnSCC})$ with standard errors for the models of the change $(\Delta)$ of milk $(\mathrm{kg})$, fat $(\mathrm{g})$, and protein $(\mathrm{g})$ production for primiparous and multiparous cows using unadjusted SCC or adjusted SCC values to selected healthy cows according to the definition of new subclinical mastitis cases ${ }^{1}$

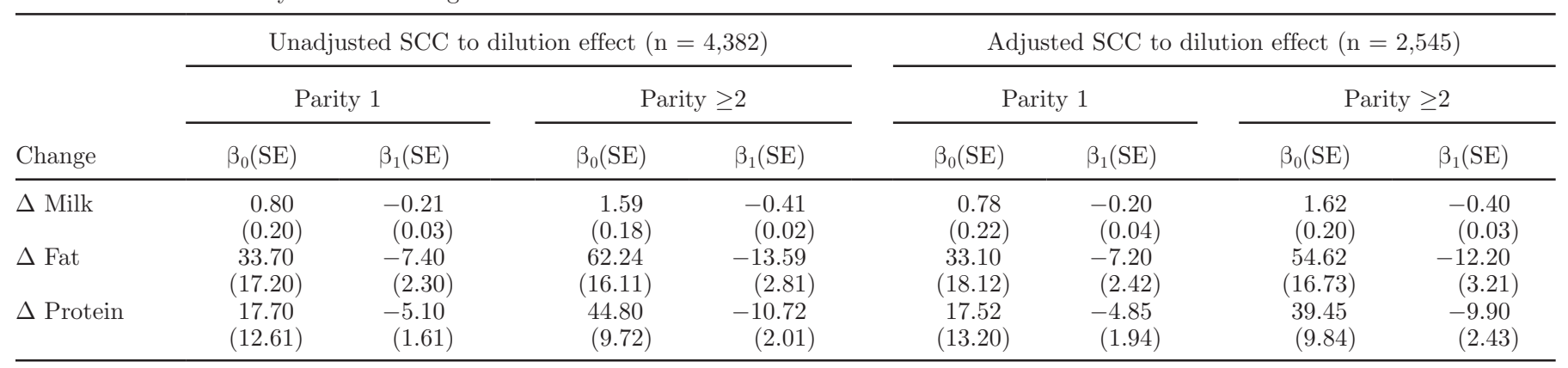

${ }^{1}$ If at test-day $(\mathrm{TD})_{i-1} \mathrm{SCC}<50,000$ cells $/ \mathrm{mL}$ and at $\mathrm{TD}_{i} \mathrm{SCC}>100,000$ cells $/ \mathrm{mL}$, a cow was considered to have a new subclinical mastitis case at $\mathrm{TD}_{i}$, where $\mathrm{TD}_{i}$ is the record at the new subclinical mastitis $\mathrm{TD}$ and $\mathrm{TD}_{i-1}$ is the previous $\mathrm{TD}$. 
Table 3. Estimates of predicted milk production loss $(\mathrm{kg} / \mathrm{d})$ together with the $95 \%$ confidence interval at different high crude SCC $\left(\times 10^{3}\right.$ cells $/ \mathrm{mL}$ ) levels for primiparous and multiparous cows using unadjusted SCC or adjusted SCC values to selected healthy cows according to the definition of new subclinical mastitis cases ${ }^{1}$

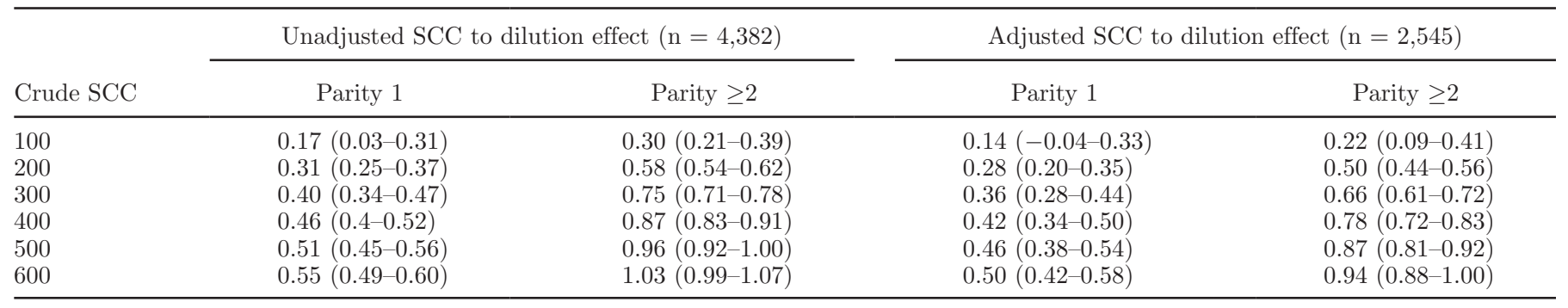

${ }^{1}$ If at test-day $(\mathrm{TD})_{i-1} \mathrm{SCC}<50,000$ cells $/ \mathrm{mL}$ and at $\mathrm{TD}_{i} \mathrm{SCC}>100,000$ cells $/ \mathrm{mL}$, a cow was considered to have a new subclinical mastitis case at $\mathrm{TD}_{i}$, where $\mathrm{TD}_{i}$ is the record at the new subclinical mastitis $\mathrm{TD}$ and $\mathrm{TD}_{i-1}$ is the previous $\mathrm{TD}$.

clustering to the right side exists in both figures, but the variances seem to be equal in both sides of the plots reflecting homoscedastic values. Figures of $\Delta$ fat and $\Delta$ protein models were similar (results not shown).

\section{DISCUSSION}

The approach used in this study (RRTM) is based on within-animal comparison, which compares the actual versus predicted production of a cow. Using this approach, the variability that is introduced because of differences between animals in different herds is eliminated. Studies that estimated production loss within cow by comparison of production before and after infection misestimated the loss, because of the effect of lactation stage on the cow-specific lactation curve as explained by Rajala-Schultz et al. (1999). Studies that estimated milk production loss due to subclinical mastitis showed low precision of the estimated loss (Hortet and Seegers, 1998). In 2 studies, the number of observations in the analysis was larger than the current study. Nevertheless, the current study estimated production loss more precisely, based on the reported standard errors in these 2 studies (Hortet et al., 1999; Koldeweij et al., 1999).

The standardized Pearson residuals showed a slightly long tail to the right side (Figures 1a and b). Although this tail might have disturbed the normality, there is no dramatic deviation from normality. Normality tests could be very sensitive to residual values, which makes the graphical demonstration the reference test (Dohoo et al., 2003). Slight disturbance might have influenced the homoscedasticity because of more observations on the right side; otherwise, the fitted values are quite homoscedastic (Figures 2a and b). Because the number of observations is different between the 2 presented analyses, comparison between model fits using the deviance or Akaike information criterion would not be correct.
Nevertheless, in both situations, the models appeared to fit the data adequately.

Fitting a specific LnSCC level in the models in Table 2 reveals the production loss at that level of LnSCC for milk, fat, and protein. Literature estimates of milk production loss for a 2-fold increase in crude SCC are 0.40 and $0.60 \mathrm{~kg} / \mathrm{d}$ for primiparous and multiparous cows, respectively, as reviewed by Seegers et al. (2003), which is close to the estimates in this study (would be 0.38 and $0.46 \mathrm{~kg} / \mathrm{d}$ for the same relationship). In this study, the clinical records were excluded from the analysis, consistent with Hortet et al. (1999) and Koldeweij et al. (1999). Reksen et al. (2007) estimated milk loss from cows with an intramammary infection in a recent pathogen-specific study. The study focused on comparing sparse and rich bacterial growth correcting for the clinical mastitis history of the cows. They found that, on average, primiparous and multiparous cows lose 0.30 and $0.66 \mathrm{~kg}$ of milk per day, respectively, corresponding to an increase of SCC to 200,000 cells $/ \mathrm{mL}$ from the healthy level $(<50,000$ cells $/ \mathrm{mL})$, which is close to the estimates of this study, but no estimates of precision in relation to SCC were provided. Moreover, Reksen et al. (2007) did not estimate the fat and protein production losses.

There was no significant effect of DIM class and season of calving on the change of milk, fat, or protein production. This was most likely because predictions of milk, fat, or protein were already corrected for DIM and season of calving. The TDInt classes did not significantly affect the change in production. This could indicate that the longer the TD interval the greater the total loss, because we assume that the loss continues from halfway between $\mathrm{TD}_{i-1}$ and $\mathrm{TD}_{i}$ to halfway between $\mathrm{TD}_{i}$ and $\mathrm{TD}_{i+1}$. The level of SCC increase appears to be the most determinant factor of the production loss (Table 3), as an indicator of the severity of inflammation (Schukken et al., 2003). The greater 


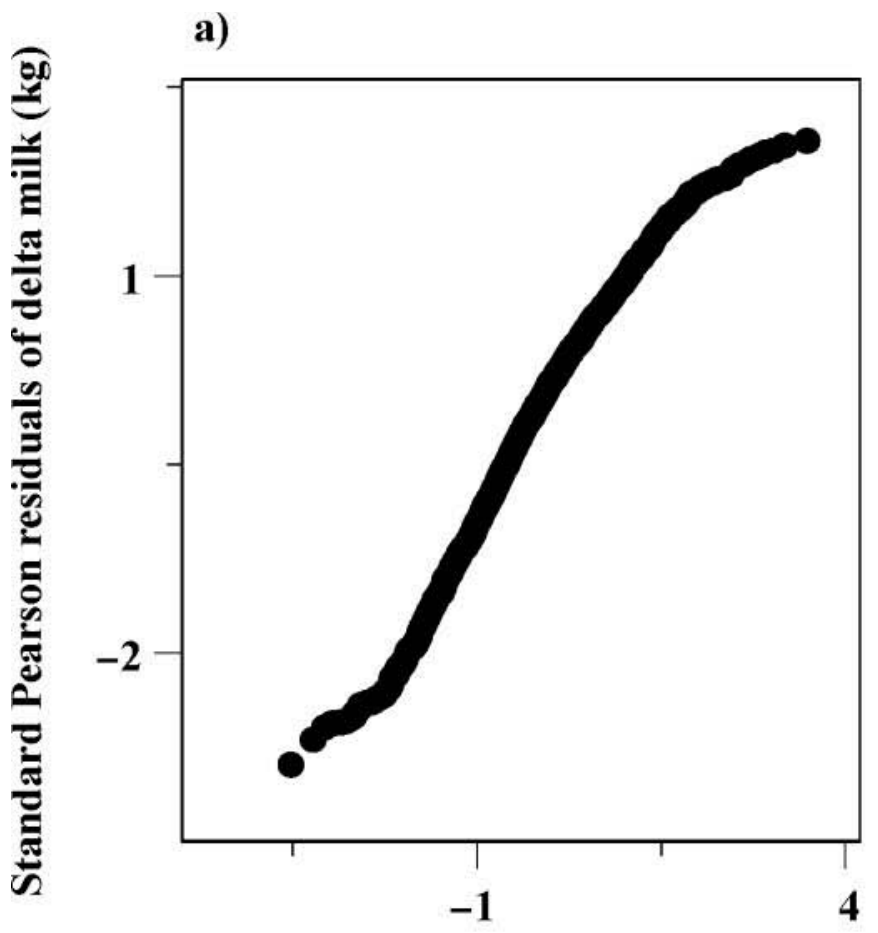

b)

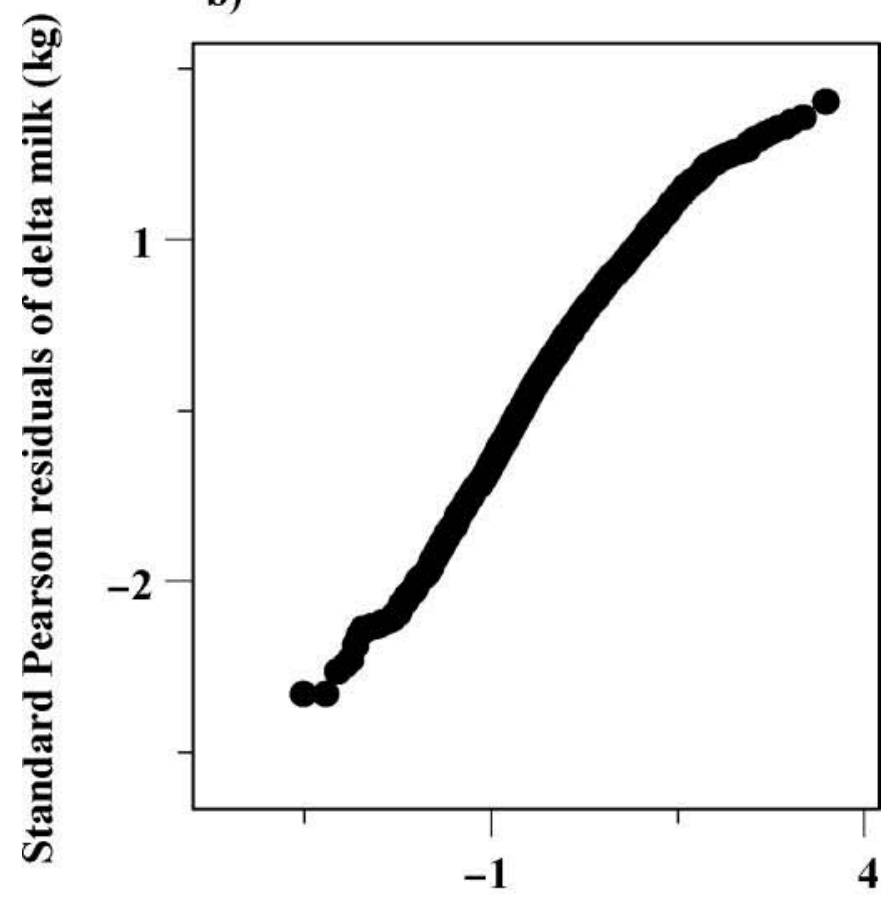

\section{Normal distribution}

Figure 1. Distribution of standard Pearson residuals of the change in milk $(\mathrm{kg})$ production models at the new subclinical mastitis test-day $\left(\mathrm{TD}_{i}\right)$ based on new subclinical mastitis definition, which considers a case if $\mathrm{SCC}>100,000$ cells $/ \mathrm{mL}$ at $\mathrm{TD}_{i}$ and was preceded by a test-day SCC $<50,000$ cells $/ \mathrm{mL}$; a) unadjusted SCC values were used to select healthy cows at $\mathrm{TD}_{i-1}$; records were 4,$382 ; \mathrm{b}$ ) only when dilution-adjusted SCC values were used to select healthy cows at $\mathrm{TD}_{i-1}$; records were 2,545 . the SCC increase $>100,000$ cells $/ \mathrm{mL}$, the greater the production loss (Table 3 ).

Fat and protein production were also affected negatively by a new case of subclinical mastitis. In many countries, farmers are paid for the fat and protein content of the milk, which makes fat and protein loss more economically important than the loss of kilograms of milk. Primiparous and multiparous cows were estimated to lose around 6 and $10 \mathrm{~g} / \mathrm{d}$ of fat, respectively, during a new subclinical mastitis with SCC of 200,000 cells/mL (Table 2). The 2 subsets showed very similar predicted losses. At the same level of SCC increase, primiparous and multiparous cows are estimated to lose 9 and $13 \mathrm{~g} / \mathrm{d}$ of protein, respectively. Previous research found fat and protein losses of 5 and $4 \mathrm{~g} / \mathrm{d}$, respectively (assuming a cow produces $25 \mathrm{~kg}$ of milk per day) per 2 -fold increase in SCC, regardless of the parity of the cow and ignoring other risk factors (Hortet and Seegers, 1998). Koldeweij et al. (1999) found a protein loss of 42 and $67 \mathrm{~g} / \mathrm{d}$ for a 1-fold increase in $\log _{10}$ SCC for primiparous and multiparous cows, respectively, which is close to the estimates in the current study.

The estimated coefficient $\lambda$ in the current study was very close to the value $(-0.485)$ found by Green et al. (2006). The coefficient means that for $1-\mathrm{kg}$-greater milk yield above $10 \mathrm{~kg} / \mathrm{d}$ for cows that had $\mathrm{SCC}<50,000$ cells $/ \mathrm{mL}$, the SCC is underestimated by $0.491 \times 10^{3}$ cells $/ \mathrm{kg}$ of milk due to dilution. Therefore, after adjustment, the SCC could be $>50,000$ cells $/ \mathrm{mL}$ at the $\mathrm{TD}_{i-1}$. The predicted milk production loss based on SCC count adjusted to dilution effect was slightly lower than the predicted loss when unadjusted SCC was used (Table 3). However, both results were presented to allow economic calculations to further investigate the importance of considering the dilution effect. Roughly, milk production loss was $13 \%$ less using the adjusted SCC compared with the crude SCC, which is in close agreement with Green et al. (2006) who found that production loss would be overestimated by $15 \%$ for crude SCC.

A general debate about the definition of a healthy cow in relation to SCC level can be inferred from the literature. Hillerton (1999) considered an udder healthy if SCC was $<100,000$ cells/mL. Djabri et al. (2002) found that the average SCC for culture-negative quarters was 68,000 cells/mL. Seegers et al. (2003), Leitner et al. (2003), and Hamann (2005) considered an udder healthy when SCC $<50,000$ cells $/ \mathrm{mL}$. We assumed a new subclinical mastitis case at a specific TD if the SCC $>100,000$ cells $/ \mathrm{mL}$ at that TD, which was preceded by healthy TD for which the SCC was always $<50,000$ cells $/ \mathrm{mL}$. This seems consistent with the recent literature on the definition of a healthy udder. The definition considered a subclinical case if a low 
a)

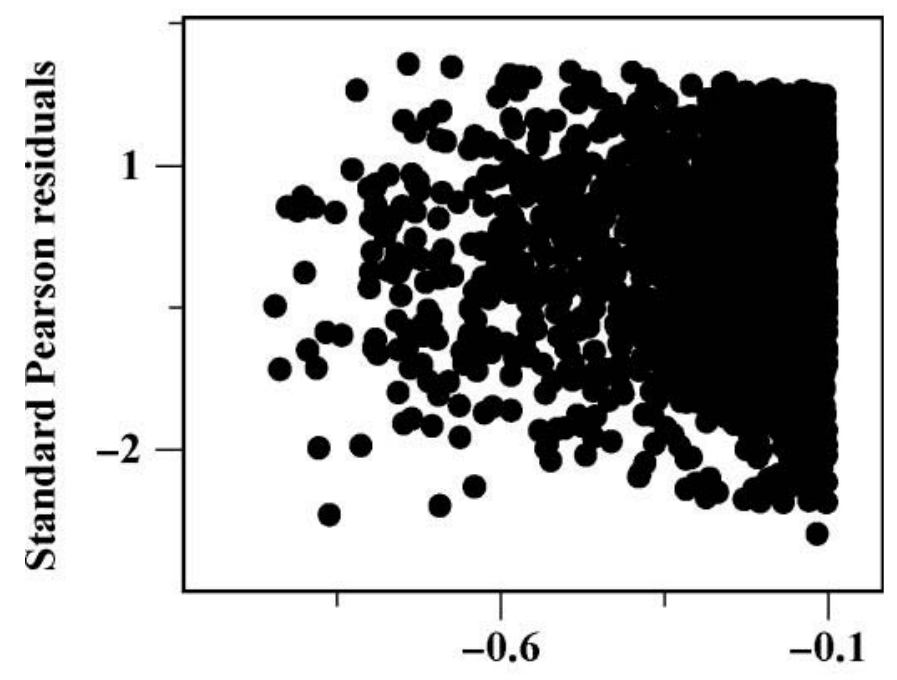

b)

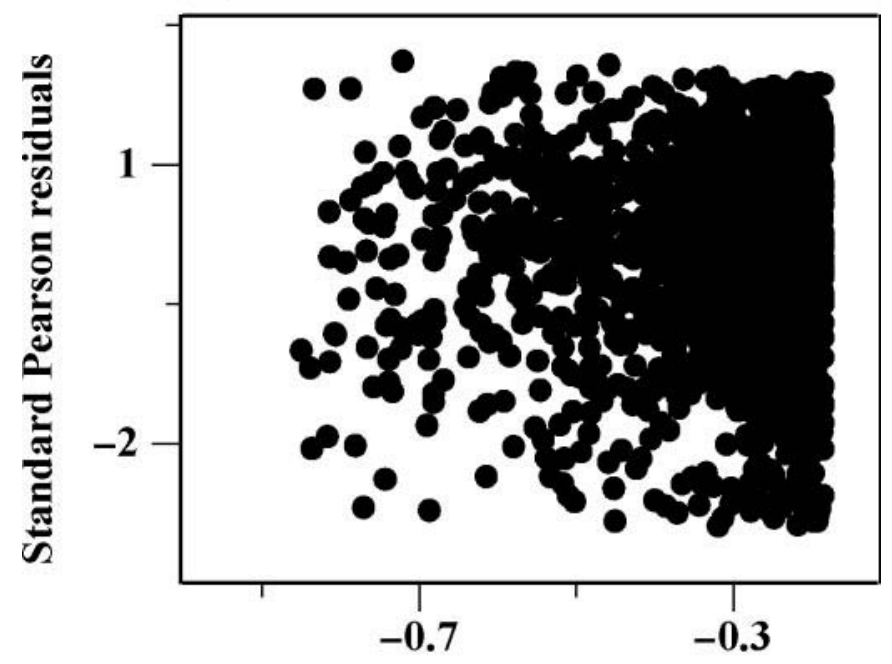

Predicted milk loss (kg)

Figure 2. Fitted values of the change in milk $(\mathrm{kg})$ production models at the new subclinical mastitis test-day $\left(\mathrm{TD}_{i}\right)$ based on new subclinical mastitis definition, which considers a case if SCC $>100,000$ cells $/ \mathrm{mL}$ at $\mathrm{TD}_{i}$ and was preceded by a test-day $\mathrm{SCC}<50,000$ cells/ $\mathrm{mL}$; a) unadjusted SCC values were used to select healthy cows at $\mathrm{TD}_{i-1}$; records were 4,$382 ; \mathrm{b}$ ) only when dilution-adjusted $\mathrm{SCC}$ values were used to select healthy cows at $\mathrm{TD}_{i-1}$; records were 2,545 .

SCC TD was followed by a high SCC TD within parity. This means, by definition, that a cow must initiate the lactation with a low SCC TD to be a new case of subclinical mastitis at the subsequent TD. This selection bias might have caused an underestimation of the loss because cows that start the lactation with high SCC TD were excluded. The analysis included only the first subclinical mastitis case per cow as an indication of new subclinical mastitis. This was imposed because we wanted to calculate the change in production based on the RRTM prediction of a healthy udder only.

\section{CONCLUSIONS}

Random regression test-day modeling is a useful method to estimate effects of a disease on production. There was a significant loss in milk, fat, and protein production of dairy cows with new subclinical mastitis, and the predicted production losses were more precise than those of earlier studies. The magnitude of losses was mainly determined by the SCC elevation of the new subclinical mastitis. The predicted losses were slightly lower when the SCC dilution effect was considered in the definition of healthy cows.

\section{ACKNOWLEDGMENTS}

The authors acknowledge the Dutch Udder Health Center (UGCN), CR-Delta, and the NRS for providing the necessary data, and Bart van den Borne, Jan van den Broek, and Hans Vernooij (Department of Farm Animal Health, Utrecht University, the Netherlands) for assistance with the data analysis.

\section{REFERENCES}

De Graaf, T., and R. H. Dwinger. 1996. Estimation of milk production losses due to sub-clinical mastitis in dairy cattle in Costa Rica. Prev. Vet. Med. 26:215-222.

De Roos, A. P. W., and G. De Jong. 2006. Genetic parameters of testday milk urea in Dutch dairy cattle. In Proc. 8th World Congress on Genetics Applied to Livestock Production, Belo Horizonte, Minas Gerais, Brazil.

De Roos, A. P. W., A. G. F. Harbers, and G. De Jong. 2004. Random herd curves in a test-day for milk fat and protein production of dairy cattle in the Netherlands. J. Dairy Sci. 87:2693-2701.

Djabri, B., N. Bareille, F. Beaudeau, and H. Seegers. 2002. Quarter milk somatic cell count in infected dairy cows: A meta-analysis. Vet. Res. 33:335-357.

Dohoo, I. R., S. W. Martin, and H. Stryhn. 2003. Veterinary Epidemiological Research. Atlantic Veterinary College Inc., Charlottetown, Prince Edward Island, Canada.

Green, L. E., Y. H. Schukken, and M. J. Green. 2006. On distinguishing cause and consequence: Do high somatic cell counts lead to lower milk yield or does high milk yield lead to lower somatic cell count. Prev. Vet. Med. 76:74-89.

Halasa, T., K. Huijps, O. Østerås, and H. Hogeveen. 2007. Economic effects of bovine mastitis and mastitis management: A review. Vet. Q. 29:18-31.

Hamann, J. 2005. Diagnosis of mastitis and indicators of milk quality. Page 82 in Proc. 4th International Mastitis Seminar, IDF, Mastitis in Dairy Production, Current Knowledge and Future Solutions. Wageningen Acad, Publ., Wageningen, the Netherlands.

Hillerton, J. E. 1999. Redefining mastitis based on somatic cell count. IDF Bull. 345:4-6.

Hortet, P., F. Beaudeau, H. Seegers, and C. Fourichon. 1999. Reduction in milk yield associated with somatic cell counts up to 600000 cell $/ \mathrm{mL}$ in French Holstein cows without clinical mastitis. Livest. Prod. Sci. 61:33-42.

Hortet, P., and H. Seegers. 1998. Calculated milk production losses associated with elevated somatic cell counts in dairy cows: A review and a critical discussion. Vet. Res. 29:497-510. 
Jamrozik, J., and L. R. Schaeffer. 1997. Estimates of genetic parameters for a test day model with random regression for yield traits of firstlactation Holsteins. J. Dairy Sci. 80:762-770.

Koldeweij, E., U. Emanuelson, and L. Janson. 1999. Relation of milk production loss to milk somatic cell count. Acta Vet. Scand. 40:47-56.

Leitner, G., R. Eligulashvily, O. Krifucks, and A. Saran. 2003. Immune cell differentiation in mammary gland tissues and milk of cows chronically infected with Staphylococcus aureus. J. Vet. Med. B $50: 45-52$.

Rajala-Schultz, P. J., Y. T. Gröhn, C. E. McCulloch, and C. L. Guard. 1999. Effects of clinical mastitis on milk yield in dairy cows. J. Dairy Sci. 82:1213-1220.

Reksen, O., L. Sølverød, and O. Østerås. 2007. Relationships between milk culture results and milk yield in Norwegian Dairy cattle. J. Dairy Sci. 90:4670-4678.

SAS Institute. 2004. User's Guide. SAS Institute Inc., Cary, NC.

Schukken, Y. H., D. J. Wilson, F. Welcome, L. Garrison-Tikfsky, and R. Gonzalez. 2003. Monitoring udder health and milk quality using somatic cell count. Vet. Res. 34:579-596.

Seegers, H., C. Fourichon, and F. Beaudeau. 2003. Production effects related to mastitis and mastitis economics in dairy cattle herds. Vet. Res. 24:475-491.

Swinkels, J. M., H. Hogeveen, and R. N. Zadoks. 2005. A partial budget model to estimate economic benefits of lactational treatment of subclinical Staphylococcus aureus mastitis. J. Dairy Sci. 88:42734287.

\section{APPENDIX}

The RRTM used data of approximately 1,000 herds in the Netherlands to predict the milk, fat, and protein production for the study data set. The model included fixed, random, and random regression effects as shown in Table A1.

Differences between cows are described by the fixed and the additive genetic effects in the model. The random effect describes the day-to-day variation within a herd. The random regression effect of herd $\times$ rolling year of test describes herd-specific lactation curves that model both differences in level of production between herds as well as differences in shape of the lactation curve between herds. The lactation curves of individual cows are described by an additive genetic effect and 2 nongenetic effects (the common and lactation-specific permanent environment effects). The cow's genetic and permanent environmental effects are also random regression effects, so they describe differences not only in level of production in each lactation, but also in shape of the lactation curve (persistency).

The accuracy of prediction is high because

1. A large number of cows in the population is used to estimate the fixed effects, so fixed effects are described in great detail and with high accuracy.

2. Records from herdmates that are not in the current trial are used to estimate the herd test date effect; that is, the day-to-day variation and seasonal patterns within the herd.

3. The additive genetic effect of the cow is used to predict production and level of production, shape of the lactation curve, and progress in production across lactations.

4. Additive genetic effects of cows are estimated accurately because most cows have sires with many progeny, and heritabilities for milk production traits are high.

5. By taking into account the permanent environmental effect of the cow, the level and shape of the lactation curve in lactations prior to the current trial is taken into account in the prediction.

6. The herd and cow effects are modeled with random regression effects, so variances and correlations within and across lactations are taken into account.

Table A1. Effects and variables included in the model

\begin{tabular}{ll}
\hline Effects & Variables included \\
\hline Fixed & Parity $\times$ DIM \\
& Parity $\times$ age at calving $\times$ month of calving $\times$ rolling 3 yr of calving $\times$ lactation stage \\
& Parity $\times$ age at calving $\times$ rolling year of calving \\
& Parity $\times$ stage of pregnancy $\times$ lactation stage \\
& Parity $\times$ length of dry period $\times$ lactation stage \\
& Parity $\times \%$ heterosis $\times$ lactation stage \\
& Parity $\times \%$ recombination $\times$ lactation stage \\
& Year $\times$ week of test \\
& Herd $\times$ test date \\
Random & Herd $\times$ rolling year of test (lactation curves for parity 1,2, and $\geq 3$ ) \\
Random regression & Additive genetic effect for cow (lactation curves for parity 1,2, and $\geq 3$ ) \\
& Common permanent environment of cow (lactation curves for parity 1,2, and $\geq 3)$ \\
& Lactation-specific permanent environment of cow (lactation curves \\
& for parity $3,4,5$, and higher) \\
\hline
\end{tabular}

